\title{
Hybrid Vehicles: a Temporary Step
}

\author{
J.J. CHANARON ${ }^{1}$ \& J. TESKE ${ }^{2}$
}

\begin{abstract}
The presented paper discusses the diffusion of hybrid electric technology in vehicles. It is put into question whether the current strong acceptance of the technology especially by US consumers is of sustainable nature. Therefore, different variables influencing the diffusion of the technology are presented and their influence on the market analyzed. It is found that nonfinancial criteria drive consumers' buying decisions significantly.

The article also presents an overview of company strategies in the field of OEMs and suppliers of hybrid electric components. It is found that most companies integrate hybrid electric vehicles in their technology portfolio.

It is concluded that even though hybrid electric technology can not yet being applied profitably yet it seems to be a key technology to the industry due to its current positive perception in the US. However, diesel technology and the intelligent use of cost efficient measures to reduce fuel consumption provide sustainable alternatives.
\end{abstract}

\section{Key words}

Automobile, hybrid technology, innovation, strategy

\section{Biographies}

Professor J.J. Chanaron (PhD, HDR) is Research Director within the French National Centre for Scientific Research (CNRS) and Chief Scientific Advisor at the Grenoble School of Management. He has published extensively books, articles in refereed journals and conference papers in Industrial Economics, Economics of Innovation and Technology Management. He is Associated Professor with Henley Management College, Manchester University and Newcastle University (UK) and Tongji University in Shanghai (China). He is a well-recognized expert in the automotive industry. He is consultant to International Organizations, professional organizations, OEMs and suppliers. In 2004, he has been granted the IAMOT award for research excellence in Technology and Innovation Management.

Julius Teske graduated in Industrial Engineering and Management at Munich University of Applied Sciences. With his background as car mechanic, he worked several years in the automotive industry in Germany and in Thailand, in the areas marketing and after sales. He obtained the Master degree in International Business at Grenoble Graduate School of Business in 2006. Focussing on Management of Technology, he intensively researched the Hybrid Electric car market in the US and proposed scenarios for 2015. Today, Julius Teske works as project leader in the automotive industry.

\footnotetext{
${ }^{1}$ Research Director CNRS and Scientific Director Grenoble Ecole de Management (GEM).

${ }^{2}$ GEM MIB graduate, Diploma in Industrial Engineering and Management at Munich University of Applied Sciences.
} 


\section{Introduction}

This article deals with the hypothesis that the recent growing craze for hybrid vehicles in the United States and Europe is simply a temporary step between the traditional technology based on gasoline and diesel engines and the forthcoming of full electric vehicles probably with hydrogen powered fuel cells. Such assumption is shared by several observers from professional as well as academic background (Ashley, 2002; Hekkert, 2004). Hekkert (2004) is the most radical challenging the idea that the emergence of hybrid vehicles might be at the expense of the fuel cell vehicle. Chanaron and Orselli (2002) suggest that hydrogen fuel cells will not be marketable in high volumes before at least 2025 and that most if not all information released so far are pure manipulation and marketing by the hydrogen lobby. The quest for low emission (clean) and high mileage vehicles is on its way and will surely remain at the top of the OEMs agenda.

Because new facts and events occur on a daily basis, such an article is inevitably out-dated as far as factual information and data are concerned. They have been up-dated up to the end of 2006. It has to be pointed out that the research is targeting only passenger cars, SUV and light commercial vehicles.

The present article is based on the following set of statements that it aims at illustrating and discussing:

- There is a general convergence of strategies towards promoting hybrid vehicles as the mid-term solution to very low emission and high mileage vehicles;

- Such a convergence is largely due to Toyota's strategy learning the technology while building up its own "quasi-standard", thanks to its high quality and reliability reputation and its high market share on the North American market;

- Such a convergence is based more on customer perception triggered by very clever marketing and communication campaigns than on pure rationale scientific arguments and may result in the need for any OEM operating in the US to have a HEV in its model range in order to survive.

Obviously, such statements lead to several unresolved questions: Is such a strategy sustainable on the long run? Or is it a short to mid term option which would then last only a few years and thus remain to limited manufacturing volumes? What are the triggers to technical choice? Is it the lowest $\mathrm{CO}_{2}$ emission or a more complex efficiency mix between cost, pollution and energy?

\section{Background}

\subsection{Literature review}

The economic and managerial literature dealing with hybrid vehicles is still very poor, basically limited to enthusiastic press coverage for newly launched models or surveys on cost efficiency (Chanaron, Faudry, 2005). Most academic publications emphasize scientific and technical issues, such as power train modeling and control, braking systems with regenerative 
devices, energy storage, energy management systems, propulsion systems, electric engines, vehicle simulation, vehicle design, etc. Most key articles limit their scope to technical efficiency (Demirdöven \& Deutch, 2004).

Within the available literature, as surveyed by Chanaron \& Faudry (2005), most publications deal with general discussion about the potential technologies and innovations limited to qualitative analysis of key drivers and success or failure factors. Most information comes from professional materials, press cuttings and interviews of key researchers and decision makers and also from previous research (Chanaron \& Nicolon, 1976; Nicolon, 1977; Chanaron, 1983, 1994, 1998). They highly reflect the point of view of industrial actors of the automotive system (de Banville, Chanaron, 1991), not to say the automotive lobby. There is hardly any interest given to consumer acceptability, pricing, etc. Amongst these qualitative surveys, there are also historical essays such as Bardou and alii (1982) and general reflections on the future of the automobile technology. The vast majority of articles and books belong to industrial economics. Very few refer to management sciences.

Struben \& Sterman (2006) start from the historic failure of the electric car at the end of the $19^{\text {th }}$ century to built a model to explore the so-called transition between two technologies, i.e. internal combustion engine (ICE) and alternative fuel vehicle (AFV), including hybrids, natural gas and hydrogen fuel cell vehicle. The authors introduce the concept of familiarity in order to capture the "cognitive and emotional processes through which drivers gain enough information about, understanding of, and emotional attachment to a technology". Awareness and familiarity are correlated with the rate of adoption. Familiarity and consumer choice is highly dependent on marketing, direct social exposure, indirect word of mouth. They conclude that the transition will be longer than usually expected and will involve a wide array of interactions and feedbacks which are not yet captured by the existing models, such as interactions with other industries and the fuel supply chain.

As far as market-related studies are concerned, it is worth mentioning Kishi \& Satoh (2005) and Sanchez-Repila \& Poxon (2006).

Kishi \& Satoh (2005) explore the evaluation of willingness to buy a low-pollution car in Japan based on a price sensitivity measurement model through a questionnaire survey run in Tokyo and Sapporo. Their research shows that the correlation between environmental awareness and willingness to buy is high as well as not surprisingly the relationship between decrease in price and willingness to buy. Their most interesting result is their evaluation of the minimum, maximum, standard and reasonable price for hybrid cars.

Sanchez-Repila \& Poxon (2006) present the different technical alternatives but also devote a specific section to market status, examining the specificity in USA, Japan and Europe. They point out the necessity of tax incentives in order to compensate for the higher prices. They also emphasize the fact that the customer motivation to buy a hybrid car seems to be environmental rather than economic, the savings in fuel being not so significant. Hybrids seem to benefit from a strong environmental and technological image or perception. The authors conclude with the obstacles to future developments of hybrids, and in particular the cost of shifting to $42 \mathrm{~V}$ supply, and they foresee no volume take off before 2010 . 


\subsection{Review of technology}

The conventional internal combustion engine (ICE), along with its limitations, builds the basis for the HEV concept. The conventional un-supercharged combustion engine only has good efficiency in a small operating range. It works efficiently at a high level of cylinder charging, that is, when its displacement is fully exploited. E.g. if an un-supercharged combustion engine is designed for a peak performance of $60 \mathrm{~kW}$ at 6000 revolutions per minute (rpm), it is basically working efficiently when it delivers $10 \mathrm{~kW}$ at $1000 \mathrm{rpm}$ or $20 \mathrm{~kW}$ at $2000 \mathrm{rpm}$. The less performance the engine needs to produce at a certain level of rpm compared to its current maximum performance, the less efficient it is. For example if the engine runs at $2000 \mathrm{rpm}$ but the driver only demands $10 \mathrm{~kW}$. According to Bohner et al. (1999), this is often the case in daily driving situations, especially in cities. The greater an engine's displacement is, the more significant the loss becomes. Consequently, when running at low revolutions, e.g. in city driving, engines with smaller displacement are more fuel efficient than engines with greater displacement. One measure getting this conceptual challenge under control is to supercharge the engine, e.g. by turbo charging or mechanical charging

The basic idea of an HEV is to work around the abovementioned challenge by running the combustion engine only at operating ranges of high efficiency. If the engines' respective peak performance is not fully needed for propulsion, mechanical performance is transformed into electric energy and then stored in a storage device, usually a battery. This energy is used to supply an electric engine which is integrated in the drive train.

Since the early nineties, the main bottleneck for full electric vehicles is their range between two recharging ${ }^{3}$ or refueling ${ }^{4}$ (Nicolon, 1977; Chanaron, 1994, 1998). No major breakthrough has been made since then despite billions of US dollars spent in R\&D, including for space exploration and promising theoretical electro-chemical options. As pointed out by Ashley (2002), "with an estimated \$6-8 billion having already been sunk into the fuel-cell industry, including both stationary and portable power types as well as transportation versions (according to analysts at Citibank)", car manufacturers (OEMs) are still struggling to take fuel cells off their laboratories and "move them onto the showroom floor".

Obviously, one of the easiest ways to extend the range of an electric car is to carry fuel and a small internal combustion engine onboard to generate electricity in order to power the electric drive train. From the viewpoint of Electric Vehicle (EV) development, hybrid vehicles convert the problem of energy storage in a battery to one concerning the storage of fuel. Such an hybrid-electric approach has been employed in the Toyota Prius and Honda Insight, which have been innovators in this market, by combining small and highly efficient combustion engines with batteries that supplement engine power when necessary (acceleration, hillclimbing, high speed motorway driving) and recovering energy when braking or the car slows down. This approach aims at increasing fuel efficiency; however the higher weight of HEVs compared to their gasoline-only cousins lower this potential.

\footnotetext{
${ }^{3}$ For batteries.

${ }^{4}$ For fuel cells.
} 


\section{Markets and diffusion}

\subsection{Evaluating markets for HEV}

The diverse degree of diffusion of the technology makes it difficult to draw one common global picture on the HEV market. Therefore, an insight to key markets is provided. Sales and registration data exist for the United States as well as for Japan. In the US, HEV sales have risen consistently since 1999 :

Figure 1. Sales of HEV vehicles in the USA

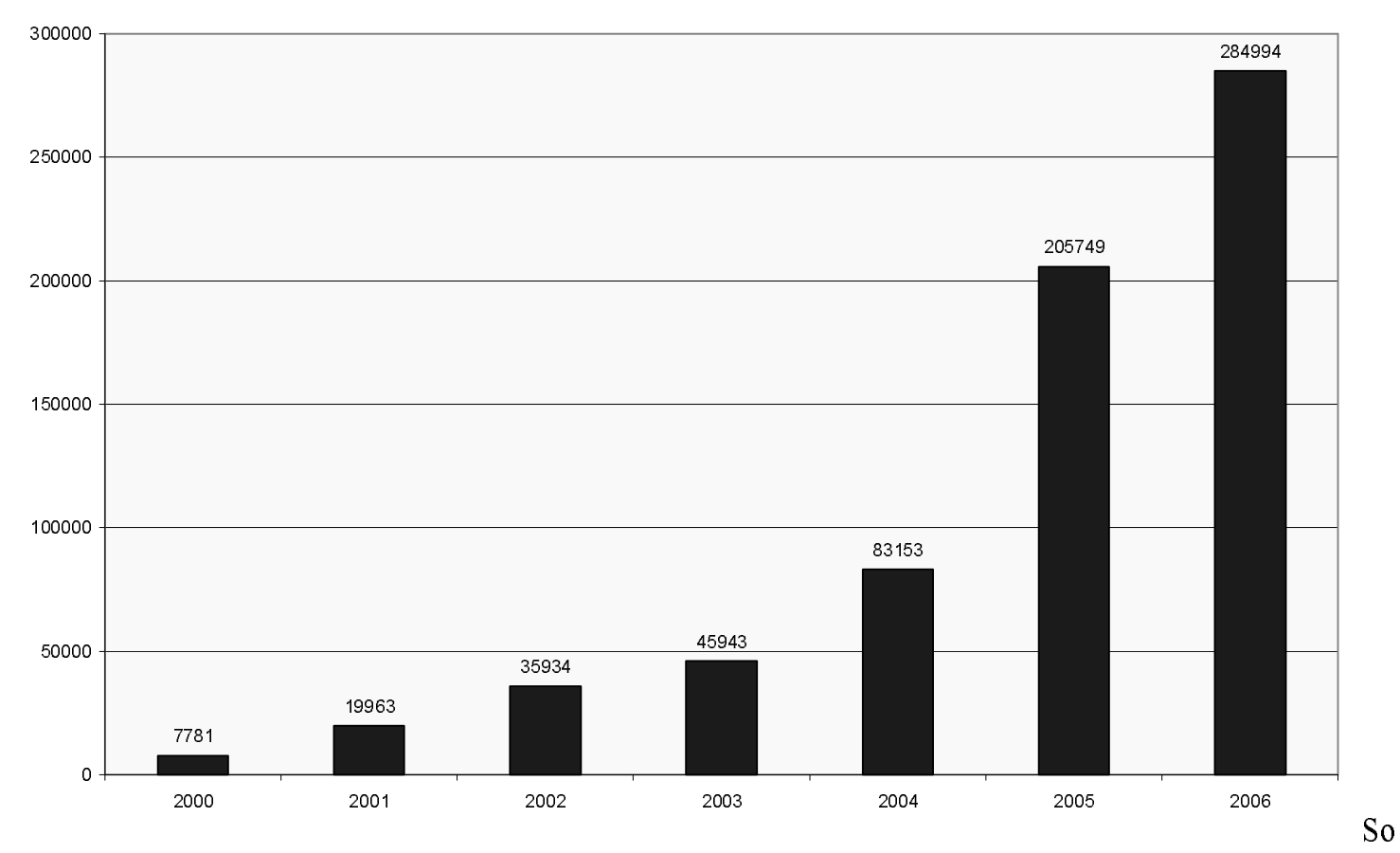

urce: Teske (2006).

As far as regional breakdown is concerned for 2005 , new hybrid vehicle registrations in California strongly outpaced all other states with 52,619 units, with Florida being second with only 10,470 units. Texas came in third with 9,632 vehicles; then New York came in fourth with 9,372 units; and Virginia rounds out the top five with 8,650 new hybrid vehicle registrations. Indeed Los Angeles remains the top metropolitan area for hybrid vehicles with 22,922 new hybrid vehicle registrations. San Francisco also kept its number two ranking with 15,828 units, followed by New York with 11,351 hybrids. Washington, D.C. came in fourth at 9,396 vehicles, followed by Boston with 3,641 new registrations.

For Japan, there are no official figures for sales of hybrid cars. The following data on hybrid vehicles in use have been published by JAMA, the OEM professional association: 
Figure 2 : Hybrid Vehicles in Use in Japan

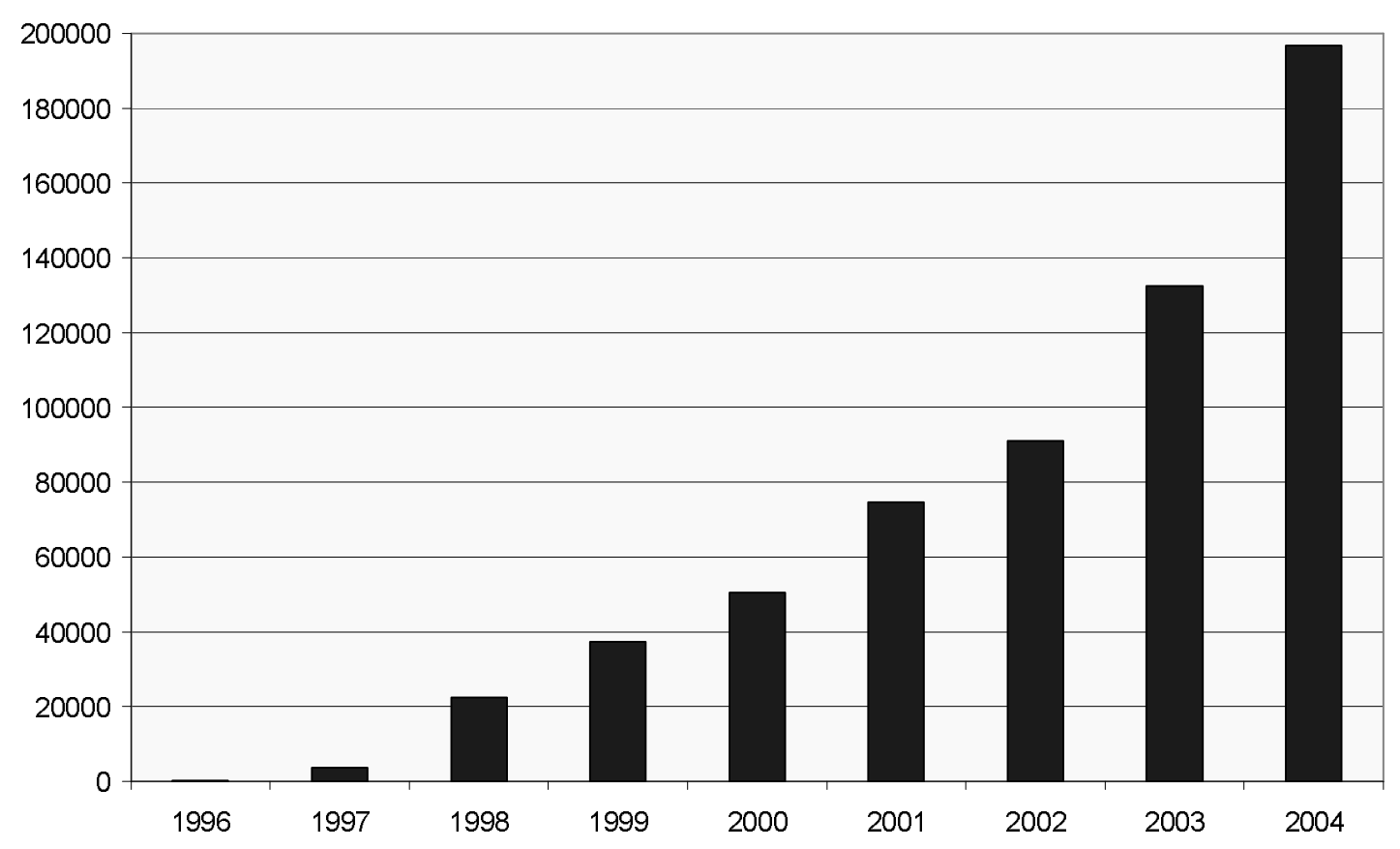

Source: JAMA.

It is indeed very difficult to foresee market share for hybrid cars in the developed countries since it is an emerging technology competing with a well-established dominant design supported by a strong lobby. For the USA, there are many forecasts of market share published by professional experts as well as university sources. For a given year, they can vary considerably: from 11\% (Mercer) to 30\% (Polk) in 2015 for instance. Some are obviously over-optimistic, some rather pessimistic. Forecasts still vary significantly over time due to adjustments and change of assumptions within the relevant key variables (see 2.2Erreur ! Source du renvoi introuvable.).

Greene, Duleep \& McManus (2004) carried out an impressive survey in the United States about perception on hybrid versus diesel powertrains in the light duty vehicle market and provided a synthesis of most professional market literature available. They elaborated scenarios for 2008, 2012 and beyond which show that market share for hybrids will remain limited and below usual expectations. 
Figure 3 :Market Share of Hybrid in 2012 in an "optimistic" scenario

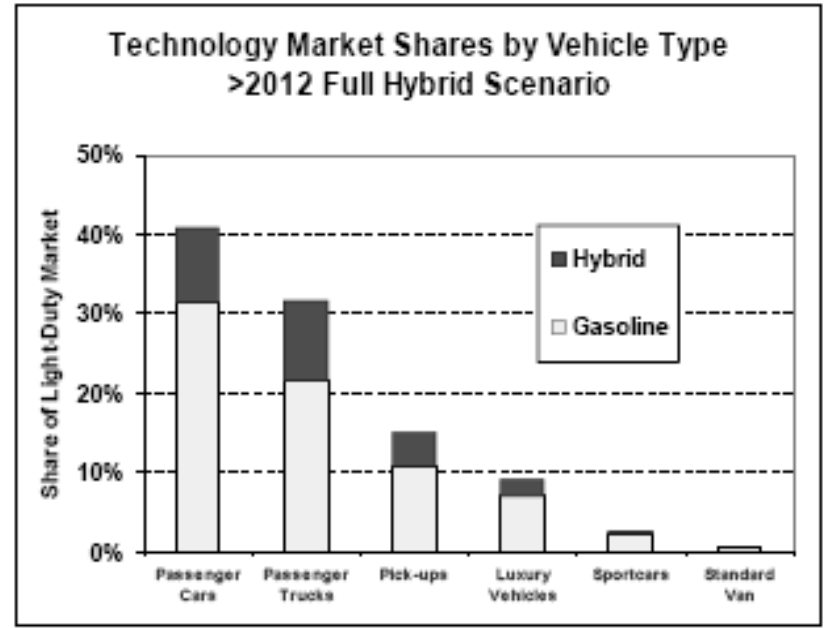

Source: Greene, Duleep \& McManus (2004).

Figure 4 : Forecast of HEV market share (US) by important consultant companies

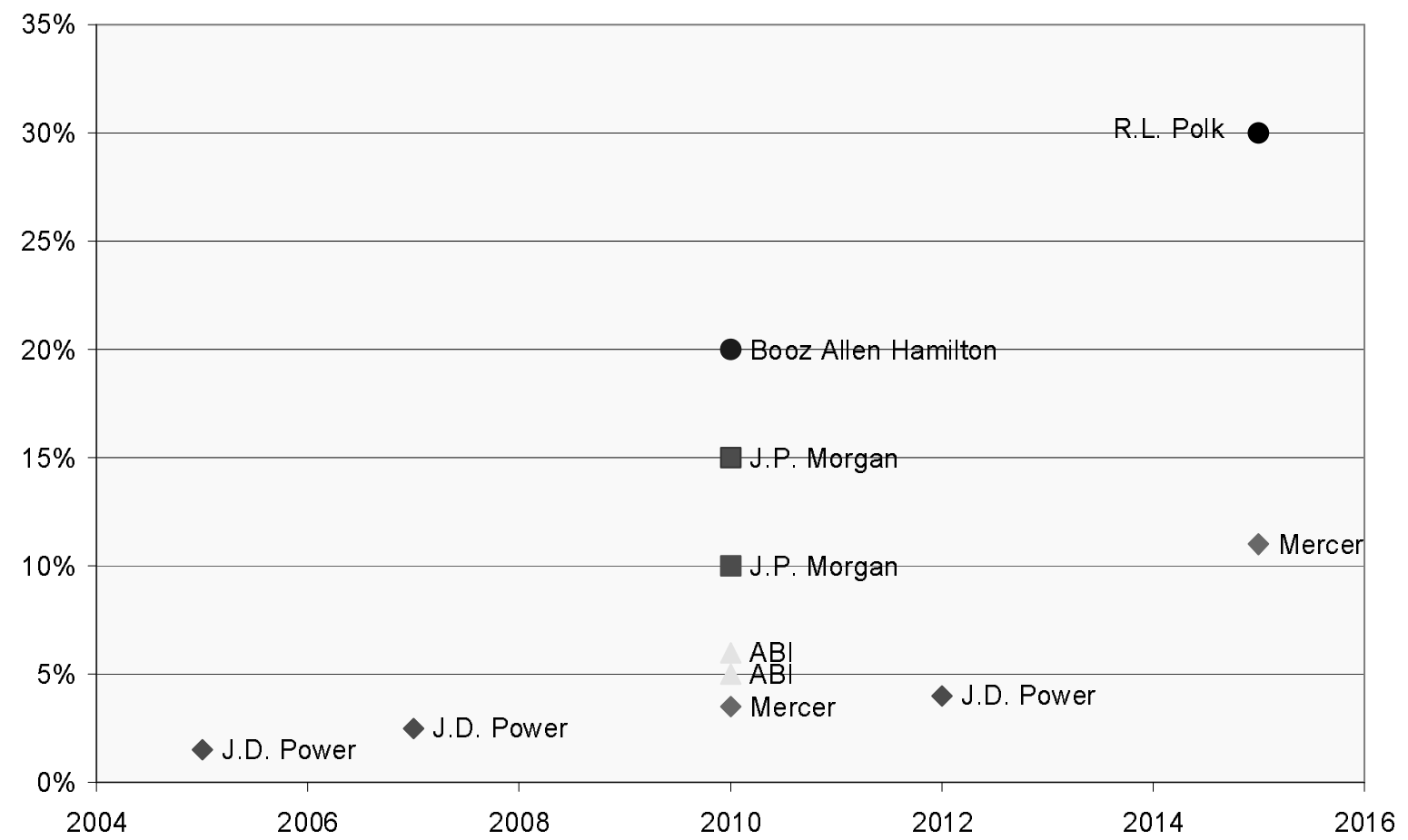

Sources: Teske (2006); press cuttings.

\subsection{Variables influencing the HEV market.}

Teske's analysis of the HEV market in the US (2006) shows that future diffusion of HEV technology is driven by different variables. These can be grouped in three categories:

- the demand side of the market, including the perception of HEV technology among consumers, cost of ownership, maintenance constraints, and sociological reasons to choose HEV technology, such as the image impact of HEV technology; 
- the supply side of the market, including the variety of HEV models offered, manufacturers' life cycle cost, characteristics of propulsion and fuel efficiency and emissions;

- as well as macro economic factors, which influence the market as a whole. Examples are the development of the fuel price, the availability and relevance of alternative technologies such as clean diesel and natural gas vehicles, regulation and taxes.

The most relevant include:

\section{Fuel Price}

Being a major driver in the cost of ownership calculation, fuel price is considered the central variable in future market scenarios. However, strong HEV sales at times of high fuel prices in 2005 and 2006 also indicate a psychological dimension of this variable: Although those fuel prices did not necessarily make the purchase of a HEV worthwhile financially (Teske, 2006), the continuous increase of the fuel price itself pushed consumers to react.

\section{Growing environmental concerns}

Environmental concerns become more and more a driver in consumers' purchase decisions. The broad public discussion on global warming due to $\mathrm{CO}_{2}$ emissions, also by cars, is impacting buying decisions of consumers. In the USA, this is leveraged by the argument of energy independence. Driving a "green car" allows people to adopt a responsible and proactive role in society. A new orientation towards ecology can be observed - in order to avoid remorse, the aspect of innovation gains importance over the classic interpretation of simply low fuel consumption.

\section{Fuel efficiency and emissions}

$\mathrm{CO}_{2}$ emissions are direct proportional to the fuel burned in the internal combustion process. Modern combustion technologies such as high precision gasoline injection allow reducing fuel consumption and lower harmful emissions such as $\mathrm{CO}, \mathrm{HC}$, and $\mathrm{NO}_{\mathrm{x}}$. $\mathrm{HEV}$ technology can help to lower emissions in different ways - by reducing a vehicle's fuel consumption through regenerative braking in stop-and-go traffic or by running the engine at highly efficient conditions.

\section{Improvement of energy storage}

Energy storage is considered the key functionality of HEVs. Functionalities like regenerative braking or additional performance for acceleration not only require high capacities of energy - the electric energy needs to be stored and released quickly. Today's HEVs mainly use batteries based on Nickel-Metal-Hydride (NiMH) technology - which is relatively heavy and expensive. Ongoing research activities focus on the exploitation of Lithium-Ion (Li-Io) technology - a lighter and more powerful alternative. However, the technology was not yet transferred to cars due to its inability to handle the quick charging and release cycles of the cars. Capacitors, as seen in the BMW X3 Efficient Dynamics, cope with this requirement, but have limited capacities compared to currently used batteries.

\section{Regulatory and Tax Regime}

In some areas of the world, regulation clearly favours HEVs above conventional ICEs. This is especially the case in the eight US states who adopted the rules of the Californian Air 
Ressource Board (CARB): New York, New Jersey, Massachusetts, Maine, Connecticut, Rhode Island, Vermont, and California. The Zero-Emission-Vehicle (ZEV) Program aims at drastically reducing emissions related to air quality. Besides setting up future emission standards, governments influence car sales with short-term interventions. Several states in the US offer tax credits in order to support hybrid sales. The tax credit becomes effective upon purchase of an HEV. Tax incentives for HEVs are reported in at least 15 states of the US and three cities; another 13 states are considering these measures (www.usatoday.com, 2006). The tax credit amount is the sum of two factors: a fuel efficiency credit and a conservation credit. The fuel efficiency credit is based on a vehicle's increase in fuel economy over a 2002 comparable vehicle standard. The conservation credit is based on the estimated lifetime fuel savings. Thus, tax credits depend on the type of HEVs. In 2005, the highest tax credit of US\$ 3,150 was granted upon purchase of a Toyota Prius.

Whereas the US tax systems clearly favour HEVs, European legislation is more divers: Currently, 11 EU member states have elements in their car and/or fuel taxation system that are totally or partly based on the car's $\mathrm{CO} 2$ emissions and/or fuel consumption. With these tax systems being very different, they fail to send a clear market signals.

In order to lower the fragmentation of the EU market, the Automobile Manufacturers Association (ACEA) is calling for a harmonized, cross-Europe $\mathrm{CO} 2$ tax on cars and alternative fuels. According to ACEA, CO2 should be the key criterion for taxation to provide incentives to buy lower $\mathrm{CO} 2$ emitting cars. Also, other than in some parts in the US, taxation should be technology-neutral to allow competition for the best solution.

\subsection{Fuel efficiency}

The most common approach to compare fuel efficiency is to look at miles per gallon or at litres per $100 \mathrm{~km}$. This approach can be also called tank-to-wheel approach (TTW), since it compares fuel efficiency after the fuel was produced and made available to the car. It is best practice when comparing cars using the same fuel with the same intrinsic energy.

However, for the comparison of cars using different fuels, the Well-to-Wheel (WTW) approach offers a holistic way to determine the overall implications of vehicle efficiency and includes the entire cycle of a fuel from the time it is extracted or produced until it is spent powering the vehicle. It also allows a more objective, technology-neutral analysis: The comparison of consumption figures is often impacted by differences in taxes on fuel and cars (see also 2.4 and 2.5). The overall WTW efficiency is divided into a well-to-tank (WTT) and tank-to-wheel (TTW) efficiency so that WTW = WTT $x$ TTW (ibid).

In their important article published in Science, Demirdöven \& Deutch (2004) present the following figure of the well-to-wheel (WTW) efficiency of the three types of vehicles (ICE, Hybrid and Fuel Cell). 
Figure 5 : Well-to-Wheel Efficiency

\begin{tabular}{|c|c|c|c|}
\hline MODEL & ICE & HICE & $A F C$ \\
\hline Simple model & 11.3 & 23.9 & 25.5 \\
\hline MIT-LFEE 2000 & 11.7 & 23.8 & $23.8-28.4$ \\
\hline ANL/GM & 15.2 & 18.6 & 24.6 \\
\hline NREL ADVISOR & 11.3 & 24.5 & 23.9 \\
\hline
\end{tabular}

Fig. 2. Comparison of WTW energy efficiencies of advanced vehicle systems using gasoline fuel. Color coding follows that in Fig. 1. 90\% WTT efficiency in all cases; thus WTW $=0.90$ TTW. Data for ICE and HICE is from (7), table 5.3. Data for AFC is from (8), which does not give energy efficiency directly. We derive a range for energy efficiency by comparing data in tables 8 and 9 for $\mathrm{MJ} / \mathrm{km}$ for vehicle and fuel cycle for the 2020 ICE hybrid to that of the gasoline FC hybrid given in (7), table 5.3. Data from (6), table 2.1. Data from NREL's ADVISOR simulation; for details, see Table 1.

Source: Demirdöven \& Deutch (2004),

Erreur! Source du renvoi introuvable.Figure 5 gives an overview of four different simulations of WTW efficiency analysis and shows that efficiency improvements in HEVs on the TTW side are mainly due to regenerative braking and energy recovery at partial load.

With many different HEV models being marketed in the US, many practical test showed controversial efficiency results: Especially when comparing to modern diesel vehicles with high pressure direct injection and turbo charging, HEVs loose out when it comes to constant driving over longer distances. Other drawbacks to the consumer are smaller trunk capacities due to volume taken by the batteries or the higher initial purchase price. HEV technology offers advantages in stop-and-go traffic, that is in cities.

\subsection{Is HEV a better alternative?}

The hybrid technology still emits some pollutants and the combined electric and mechanical drive-trains are a complex and costly solution. According to Ashley (2002), OEMs "must subsidize current hybrid car models heavily to make them affordable". The Toyota Prius costs currently 4,000 US\$ more than a comparable Corolla ${ }^{5}$. On the American market, the hybrid version of the Honda Civic was sold 2,500 US\$ more than the gasoline version. This is at the purchasing cost level. But their most recent hybrid models, such as Prius II and Honda Insight and Civic, are cheaper to run as indicated by their mileage records (Figure 6):

\footnotetext{
${ }^{5}$ Nihon Keizai Shimbun, 13/09/2005.
} 
Figure 6 : Real Hybrid Mileage Database

41,637,141 miles, 33,380 tanks, 2,558 cars within GreenHybrid database

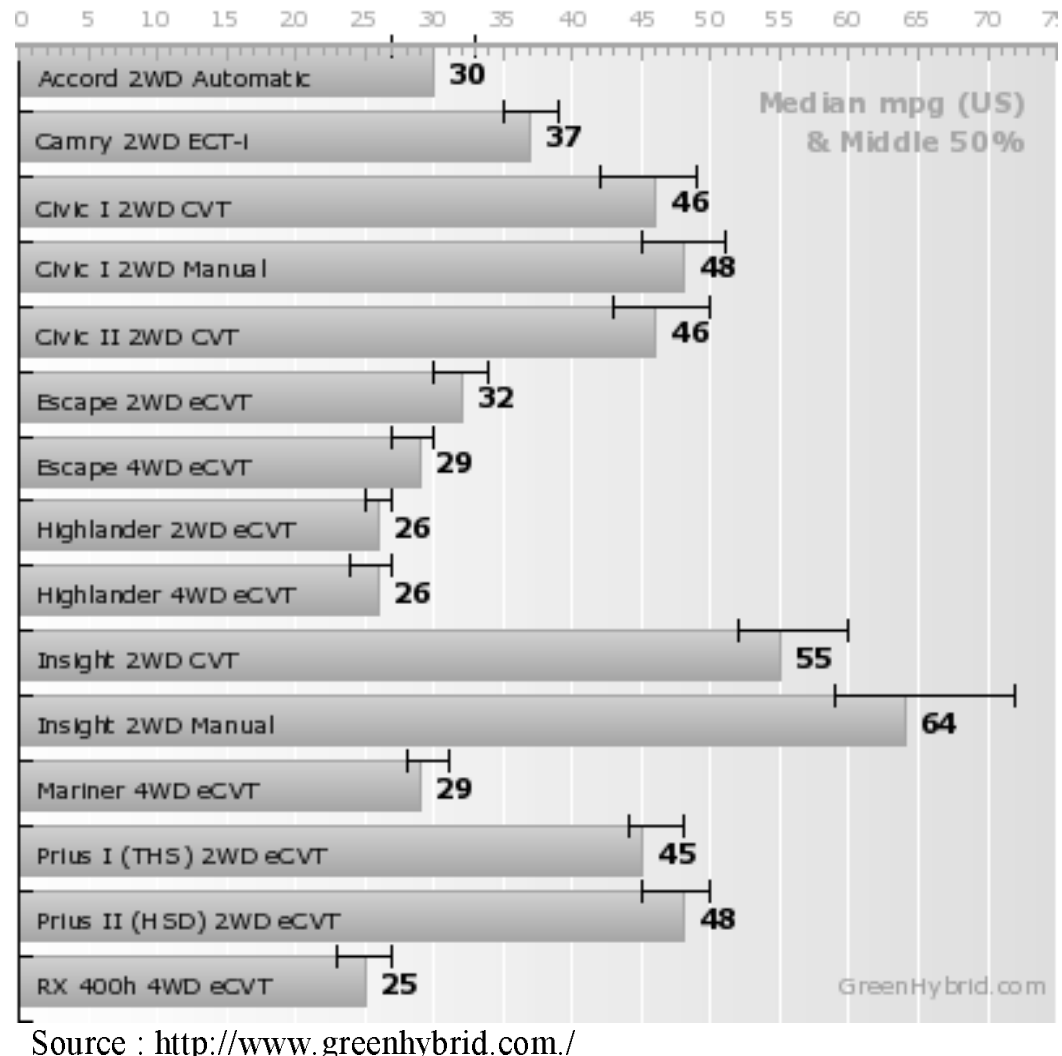

Consumers buying decisions are more and more driven by a car's fuel economy. This is mainly due to increasing fuel prices. Consequently, if a HEV's higher initial purchase price can be compensated by savings on fuel, the investment is worthwhile financially. As Teske (2006) pointed out in an analysis on cost of ownership, other cost drivers are taken into account:

- Tax advantages, such as credits granted in the USA upon a HEV purchase, help compensating the higher purchase price.

- The expected resale price of a HEV is still difficult to predict due to the absence of experience. In 2006, most HEVs on the used-car market sold at relatively high prices, which can be explained by the high demand and the limited offer of new models during that time.

- To date, cost for maintenance and repair are very low, because most HEV manufacturers grant long term warranty periods on HEV components in order to avoid obvious constraints of the new technology. E.g. Toyota's HEV related components are covered by an eight year warranty.

The analysis, conducted for the US market, showed that in general the purchase of an HEV does not allow significant financial benefits for consumers. However, an analysis of the situation in France by Captital (2006) shows a different conclusion.

Here, the hybrid option looks attractive, in particular thanks to the decrease in fuel cost and to the tax incentive (Table 1). 
Table 1 : Total Cost over 4 Years

\begin{tabular}{|l|c|c|c|c|c|c|c|c|}
\hline & \multicolumn{2}{|c|}{ Toyota Prius } & \multicolumn{2}{c|}{ Honda Civic } & \multicolumn{2}{c|}{ Lexus 4WD } & \multicolumn{2}{c|}{ Citroën C3 } \\
\hline & Gasoline & Hybrid & Gasoline & Hybrid & Gasoline & Hybrid & Gasoline & Hybrid \\
\hline Purchasing & 21,750 & 24,950 & 20,200 & 22,100 & 50,550 & 56,000 & 15,580 & 15,500 \\
\hline $\begin{array}{l}\text { Tax } \\
\text { Incentive }\end{array}$ & & $-1,525$ & & $-1,525$ & & $-1,525$ & & \\
\hline Fuel & $\mathbf{8 , 7 3 0}$ & 4,501 & $\mathbf{8 , 1 4 0}$ & $\mathbf{5 , 0 8 5}$ & 12,165 & 6,544 & 7,298 & 5,849 \\
\hline Insurance & 2,514 & 1,835 & 2,514 & 1,835 & $\mathbf{5 , 0 9 1}$ & $\mathbf{5 , 0 9 1}$ & 1,960 & 1,837 \\
\hline TOTAL & $\mathbf{3 2 , 9 9 4}$ & $\mathbf{2 9 , 7 6 1}$ & $\mathbf{3 0 , 8 5 4}$ & $\mathbf{2 7 , 4 9 5}$ & $\mathbf{6 7 , 8 0 6}$ & $\mathbf{6 6 , 1 1 0}$ & $\mathbf{2 4 , 8 3 8}$ & $\mathbf{2 3 , 1 8 6}$ \\
\hline
\end{tabular}

Source: Capital, Septembre 2005, pp. 102-103.

With financial benefits being not significant, there must be other drivers to the current success of HEVs in the US. A recent study conducted by Topline Strategy Group (2007) concludes that HEV drivers do not focus solely on financial performance. It is also some kind of environmental virtue driving the purchase decision. In the US, driving a hybrid car shows social responsibility to many consumers. This is also due to successful marketing of the hybrid label by the early adopters Toyota and Honda. It is not necessarily the expected lower $\mathrm{CO} 2$ output of ones car; the image attached to driving a hybrid car also creates value for HEV drivers

\subsection{Pricing}

As highlighted above, the higher purchase price is a barrier to a faster diffusion of HEV technology. However, the price surplus differs significantly, taking into account regional and demographical preferences. As suggested by Teske (2006), the higher purchase price of an HEV can not only be compensated by savings over the car's lifetime; the technology also brings value of non-financial, i.e. qualitative nature. Examples are e.g. the surplus in torque delivered by the electric engines and the low noise during electric-only propulsion. Another important qualitative feature is the technology's image of social responsibility and sustainability. E.g. Toyota successfully shaped these characteristics by strong marketing activities in the US. These activities were leveraged by continuously rising fuel prices and an ongoing public discussion on climate change.

The issue of an "ideal pricing" for hybrid cars has been raised by Kishi \& Satoh (2005). They suggest the following prices for ICE and hybrid cars on the Japanese market:

Table 2 : Prices for ICE and Hybrid Cars in Japan in US\$

\begin{tabular}{|l|c|c|c|c|}
\hline & \multicolumn{2}{|c|}{ Tokyo } & \multicolumn{2}{c|}{ Sapporo } \\
\hline & ICE & Hybrid & ICE & Hybrid \\
\hline Minimum Price & 13,125 & 12,631 & 13,338 & 225 \\
\hline Maximum Price & 28,535 & 28,007 & 26,677 & 19,924 \\
\hline Standard Price & 21,222 & 20,932 & 20,148 & 17,498 \\
\hline Reasonable Price & 15,716 & 15,154 & 16,049 & \\
\hline
\end{tabular}

Source: Kishi \& Satoh, 2005. Exchange rate at 31/08/2006 is 1,000 yen $=8,523$ US\$

They also calculate the best pricing for the discount segment and the premium segment: 
Table 3 : Prices for Hybrid Discount and Premium Cars in Japan in US\$

$\begin{array}{lcc} & \text { Tokyo } & \text { Sapporo } \\ \text { Discount Market } & 14,583 & 14,625 \\ \text { Premium Market } & 28,007 & 25,424 \\ \text { Source: Kishi \& Satoh, } 2005 \text {. Exchange rate is } \\ \text { 1,000 yen }=8,523 \text { US\$ }(31 / 08 / 2006) .\end{array}$

Table 2 and Table 3 describe the results published by Kishi \& Satoh (2005) on "acceptable pricing" for HEV in Japan for better consumer acceptance and then for a fast growth of market shares.

At industry level, even if there is a consensus on the risk associated with a too expensive premium for clean vehicles, there are obviously diverging philosophies and approaches.

Nissan is considering that the market price of a fuel-cell powered vehicle should be not more than 1.2 times the price of a conventional car by $2015^{6}$.

The pricing issue is indeed a key one. Since the price premium for HEV technology compared to comparable conventional gasoline vehicles is estimated at US $\$ 4,000$ per vehicle ${ }^{7}$, it means that so far, the OEMs can not profitably sell HEV. The Ford Escape Hybrid market price is US\$ 3,300 more expensive than its gasoline version and the Honda Civic is US\$2,400 dearer that the traditional Civic.

In some countries, the gap is partly filled up by Government grants: $€ 2,000$ in France for instance ${ }^{8}$. In the United States, it was US\$ 3,150 up to $1^{\text {st }}$ September 2006. Since then it is US\$ 1,575 and then US\$ 780 on $1^{\text {st }}$ March 2007.

\section{Corporate strategies}

\subsection{OEMs}

As the prime innovator, Toyota is indeed in a favourable position to achieve huge economies of scale through:

1. Expanding the number of models within its own range and its different brands;

2. Sharing its technology as well as the cost of further R\&D in order to prepare the next generations of devices to its affiliates such as Daihatsu', Fuji Heavy (Subaru) ${ }^{10}$;

3. Supplying its technology to competitors such as Nissan, GM, etc.

Toyota is planning to lower the production cost of the hybrid system by $30 \%$ and to reduce the gap in price from $3,500 €$ to $2,000 €^{11}$. Toyota produced 230,000 hybrid cars in 2005 , 312,500 in 2006 and sold 998,900 HEVs worldwide until april 2007. For 2007, Toyota

\footnotetext{
${ }^{6}$ Nihon Keizai Shimbun, 05/09/2006.

${ }^{7}$ Les Echos, 05/10/2006.

${ }^{8} € 3,000$ is an old vehicle is dismantled.

${ }^{9}$ Nihon Keizai Shimbun, 30/08/2005.

${ }^{10}$ Nihon Keizai Shimbun, 26/11/2005.

${ }^{11}$ Nihon Keizai Shimbun, 01/04/2006.
} 
expects to sell 430,000 units, including 300,000 in the US. The official objective is 1 million units from 2010 with a range of 10 models, of which 600,000 sold in the United States ${ }^{12}$. At the end of 2006, Toyota started to produce the Hybrid Camry in the United States.

Toyota will offer a small hybrid Vitz (in Europe Yaris) in 2010 and a large hybrid Crown in 2008. The world leader is still controlling the manufacturing of key components for HEV in its own plants as well as through its partner component suppliers such as Denso.

Honda is indeed the main competitor to Toyota because the closest as far as technology and knowledge about hybrid are concerned. Honda has already several models, even if they are sold in smaller volumes. Honda has less ambitious targets: 200,000 units by 2010 when 50,000 were sold in 2005 .

Regarding other OEMs, some are enthusiastic "pros", even if it is by necessity, other are cautious "pros" and a few are very reluctant. Amongst the "enthusiastic pros" one could find:

- GM, which found itself in the position to accelerate its programme for hybrids because it was loosing market share at the benefits of Toyota and Honda. From 2006, an ambitious range is under development with hybrid version of big SUVs such as Chevrolet Tahoe and GMC Yukon (late 2007), light trucks such as GMC Sierra and Chevrolet Silverado (2008 on a new technology designed with DaimlerChrysler and BMW). In 2007, two sedans, the Chevrolet Malibu and the Saturn Vue Greenline will be offered as well. GM already warned officially that these products "will lose money...because it is early stage technology and the volume is low"13. At the 2007 Detroit Motor Show, GM revealed a rechargeable hybrid (plug-in hybrid) - Chevrolet Volt - with a lithium-ion battery and a small three-cylinder engine, allowing a $65 \mathrm{~km}$ ride on the battery ${ }^{14}$. A plug-in hybrid Saturn Vue is also currently prepared ${ }^{15}$;

- Saab, a GM subsidiary, is developing an ethanol-electric hybrid in Trollhättan to be launched in 2008;

- Ford, which has launched also an ambitious programme targeting 250,000 units by 2010, but is struggling to sell its hybrid models. In 2005, Ford sold only 17,000 units of the Ford Escape and the Mercury Mariner with a manufacturing capacity of 2,000 units per month, and then initiated a 1,000 US $\$$ discount and a $0 \%$ credit in 2006 ;

Amongst the more cautious "pros", one could position:

- Hyundai, the leading Korean OEM, which has chosen a stand alone strategy, delivering 350 prototypes of its Verna to the Government for testing and evaluation and expecting to initiate production not by the end of 2006 as initially announced but in 2009. The objective to reach a total output of 300,000 units by 2010 is then postponed to a later date $^{16}$;

\footnotetext{
${ }^{12}$ Les Echos, 13/03/2006.

${ }^{13}$ R. Wagoner, CEO, quoted in Financial Times, 19/09/2005.

${ }^{14}$ Financial Times, 08/01/2007.

${ }^{15}$ Financial Times, 30/11/2006.

${ }^{16}$ Korea Herald, 19/05/2006.
} 
- Kia, which also sold around 400 units of its Click hybrid to the Korean Government and also postponed the production to $2009^{9}$;

- Peugeot-Citroën in France, which is quite reluctant on developing hybrid vehicles. It has designed with Ricardo (UK) and QinetiQ (UK) ${ }^{17}$ a prototype of the Citroën Berlingo thanks to grant given by the British Government through its "Ultra Low Carbon Car Challenge" project. Citroën is marketing the C3 "Stop and Start" hybrid since mid-2005 Peugeot-Citroën will lead the consortium funded by the French Government within the Predit R\&D initiative, together with Valeo, Bosch, Saft and Michelin ${ }^{19}$;

- Nissan, the Renault associate, which appears to lag behind its main competitors, Toyota and Honda, and which might be used as the pilot test partner. In 2002, Nissan signed an agreement with Toyota to use its technology: a Nissan Altima hybrid is due to be launched in the US in 2007. With its in-house solution, Nissan announced an hybrid car for $2010^{20}$;

- BMW is indeed actively developing a hybrid technology. A hybrid BMW is due before 2010 and a hybrid Mini is prepared for 2013-2014 ${ }^{21}$. BMW cooperates with DaimlerChrysler and GM in order to develop a first generation hybrid drive. To date, BMW offers different measures to increase fuel efficiency under their label "Efficient Dynamics", including start-stop automatic, brake energy regeneration, and high precision injection in gasoline engines.

Amongst the most reluctant, not to say opponent OEMS, one could classify those which are still at the R\&D or the prototype level:

- Mazda, a partner to Ford;

- Volvo cars, also a Ford subsidiary;

- Renault, which stated that hybrid cars will remain a niche market;

Strategic alliances are one of the ways to overcome or at least contain Toyota's domination:

- BMW, DaimlerChrysler and GM formed in August 2005 a consortium for developing in its Troy (Michigan) research centre and producing hybrid cars ${ }^{22}$. Mercedes Benz has launched two hybrid versions of its S Class during the 2005 Frankfurt Motor Show;

- GM has released that it will produce hybrid vehicles in China in partnership with SAIC by $2008^{23}$. GM will also launch "as soon as possible" an hybrid vehicle designed with Suzuki $^{24}$;

\footnotetext{
${ }^{17}$ Le Parisien, 10/09/2005.

${ }^{18}$ Capital, Septembre 2005.

${ }^{19}$ Les Echos, 26/04/2006.

${ }^{20}$ Financial Time, 11/12/2006.

${ }^{21}$ Die Welt Am Sonntag,, 29/10/2006.

${ }^{22}$ L'Expansion, Octobre 2005.

${ }^{23}$ Wall Street Journal, 31/10/2005

${ }^{24}$ El Mundo, 08/01/2007.
} 
- The VAG Group (VW, Audi) and Porsche are jointly designing hybrid vehicles and are expected to market hybrid versions of the VW Touareg, the Audi Q7 and the Porsche Cayenne SUV in $2008^{25}$. A VW Jetta is due to sold in the US in $2009^{26}$;

- It is also the way used by Nissan through a strategic cooperation with its competitor.

Surprisingly, the Chinese OEMs are also involved in the race for the expected growing domestic market for hybrid cars:

- Chery et Geely might commercialize hybrid models by 2007 and Nanjing is preparing an hybrid version of the Rover 75, with a technology derived from the Toyota Prius ${ }^{27}$.

As far as trucks are concerned, Volvo presented a diesel electric hybrid system to be launched in 2009. Volvo Trucks expects that this technology will take $10 \%$ of its turnover since its customers will see a 25 to $50 \%$ saving in petrol consumption despite a higher investment ${ }^{28}$.

\subsection{Component and system suppliers}

Component manufacturers struggle to keep up with the pace HEV technology was developed by the first OEMs.

- Continental and ZF Friedrichshafen expect to produce together hybrid engines, including braking and associated electrical components by 2007. ZF did develop a gear box integrating the electric engine. Continental is also cooperating in design and development with Volkswagen ${ }^{29}$;

- Bosch, one of the world largest component manufacturers, has recently decided to invest heavily in hybrid components, realizing that such technology will take one percent of the total vehicle registrations by 2010 , i.e. around 700,000 vehicles, and $5 \%$ in $2025^{30}$.

- Hitachi is one of the key suppliers of electric engines for the Toyota Harrier and Kluger, being the first component manufacturers non affiliated to Toyota to be involved in the hybrid business ${ }^{31}$;

- Panasonic EV Energy, making batteries nickel-metal-hydride (Ni-Mh) for hybrid, been taken over by Toyota ( $60 \%$ of its stockholding);

- Johnson Controls (51\%), world leader in automotive batteries, and SAFT (49\%) formed a joint venture to develop lithium-ion (Li-ion) batteries for hybrid vehicles ${ }^{32}$. A new plant will be operational in France (Angouleme) with an investment worth US $\$ 20^{33}$;

\footnotetext{
${ }^{25}$ Suddeutsche Zeitung, 13/09/2005.

${ }^{26}$ Autocar, 27/12/2006.

${ }^{27}$ Auto Journal, 07/12/2006.

${ }^{28}$ Dagens Industri, 21/12/2006.

${ }^{29}$ Frankfurter Allgemeine Zeitung, 10/06/2006.

${ }^{30}$ Automotive News Europe, 10/06/2005.

${ }^{31}$ Nihon Keizai Shimbun, 10/10/2005.

${ }^{32}$ Les Echos, 12/10/2005.

${ }^{33}$ Les Echos, 22/09/2006.
} 
- Sanyo, the leading Japanese battery manufacturer and key supplier to Toyota, Honda, Ford and others ${ }^{34}$, has teamed up with Volkswagen for developing and supplying batteries and control systems for hybrids;

- On the high-voltage wiring market for hybrids, Yazaki, which supplies the batteries for the Toyota Prius and the Lexus UX 400h crossover hybrid, is expanding in the United States to supply the Toyota Camry Hybrid and the Ford Escape. Yazaki's competitors include Sumitomo Electric Industries Ltd., Hitachi Automotive Products Inc., Lear Corp. and Delphi Corp.

- Two multinational component manufacturers, Siemens VDO and Magna International, cooperate in developing a hybrid vehicle on the basis of a Mercedes Benz ML350, reducing fuel consumption by $20 \%$.

\subsection{The emergence of new players}

\subsubsection{AFS Trinity Power Corporation}

AFS Trinity Power is headquartered in Bellevue, Washington and has an engineering center in Livermore, California. This company has developed a new hybrid technology and claimed it is much more efficient than current options ${ }^{35}$. It is a Plug-in hybrid electric vehicles (PHEVs). The three plug-in designs that are mentioned most often today are: various plug-in conversions of the Toyota Prius; the Daimler Chrysler Sprinter van; and the AFS Trinity Extreme Hybrid ${ }^{\mathrm{TM}}\left(\mathrm{XH}^{\mathrm{TM}}\right)$. AFS Trinity published the following benchmarks:

\footnotetext{
${ }^{34}$ Supplying for the Ford Escape and Honda Accord, see Nihon Keizai Shimbun, 31/01/2006.

${ }^{35}$ Les Echos, 10/05/2006. See the company's website at http://www.afstrinity.com.
} 
Table 4: Characteristics and Performances of AFST Extreme Hybrid

\begin{tabular}{|c|c|c|c|c|}
\hline Model & $\begin{array}{c}\text { CalCars } \\
\text { Prius+ } \\
{[1]} \\
\end{array}$ & $\begin{array}{c}\text { Energy } \\
\text { CS Prius } \\
{[2]} \\
\end{array}$ & $\begin{array}{c}\text { DC } \\
\text { Sprinter } \\
\text { Van }\end{array}$ & $\begin{array}{c}\text { AFST Extreme } \\
\text { Hybrid }^{\text {TM Sedan }} \\
{[4]}\end{array}$ \\
\hline Energy Storage Technology & $\begin{array}{c}\text { Lead-acid } \\
\text { Battery }\end{array}$ & $\begin{array}{l}\text { Li-ion } \\
\text { Battery }\end{array}$ & $\begin{array}{l}\text { NiMH } \\
\text { Battery }\end{array}$ & $\begin{array}{c}\text { Li-ion Battery + } \\
\text { U1tracapacitor }\end{array}$ \\
\hline Energy Storage Capacity (kWh) & $3-4$ & 9 & 14.4 & $\begin{array}{c}12.5+ \\
\text { Ultracapacitor }\end{array}$ \\
\hline Electric-only Range (miles) & $10[5]$ & $30[5]$ & $20-30[6]$ & 40 \\
\hline Top Speed in Electric-only mode (mph) & 34 & 34 & Not given & 110 \\
\hline $\begin{array}{l}\text { Electric-only Optimum } \\
\text { Freeway Speed Operating } \\
\text { Range (mph) }\end{array}$ & N.A. [7] & N.A. [7] & Not given & $55-75$ \\
\hline Top Speed in Hybrid Mode (mph) & $\begin{array}{l}\text { Same as } \\
\text { std. Prius }\end{array}$ & $\begin{array}{l}\text { Same as } \\
\text { std. Prius }\end{array}$ & Not given & 110 \\
\hline Rated Fuel Economy [3] & $100 \mathrm{mpg}$ & $100 \mathrm{mpg}$ & Not given & $250 \mathrm{mpg}$ \\
\hline Battery Life & 11 months & Not given & Not given & $\begin{array}{c}10 \text { years/ } \\
150,000 \text { miles }\end{array}$ \\
\hline
\end{tabular}

\section{Notes}

1. CalCars first generation prototype Prius conversion.

2. EnergyCS Prius conversion.

3. Based on 300-mile weekly drive cycle with 40 miles per day on 5 weekdays and 100 miles on one weekend day. This allows the XH'M to operate in electric-only mode for 240 miles and in HEV mode for 60 miles.

4. Extreme Hybrid ${ }^{\mathrm{TM}}$ specifications are subject to change as development of the $\mathrm{XH}^{\mathrm{TM}}$ drive train continues.

5. See CalCars PHEV Conversions Fact Sheet-April 20, 2006, PHEV Battery Comparison Chart.

6. “A Giant Stride for the Future of Electric Transportation", EPRI Pamphlet, 2004.

7. With maximum electric-only speed of 34 mph Prius+ operation on freeways requires use of its gas engine.

\subsubsection{Amberjac Projects \& EnergyCS}

Two design companies, Amberjac Projects (UK) and EnergyCS (California, USA), developed the Plug-in hybrid version of a Toyota Prius 2004, equipped with a lithium-ion-phosphates which from $55 \mathrm{~km} / \mathrm{h}$ is running on gasoline at 2,5 liter $/ 100 \mathrm{~km}$. The conversion kit will be sold $10.000 €$ by the end of $2006^{36}$. The battery is still too heavy and this weight should be reduced by $35 \mathrm{~kg}$.

\subsubsection{SVE}

SVE is a French joint-venture between Heuliez and Dassault which has developed a hybrid car named Cleanova Plus equipped with a bio ethanol engine ${ }^{37}$.

\footnotetext{
${ }^{36}$ Usine Nouvelle, 27/10/2005.

${ }^{37}$ Le Figaro, 27/09/2006.
} 


\subsubsection{Swatch}

Nicolas Hayek, the Swiss entrepreneur, CEO of Swatch, has developed a HEV and is currently negociating with OEMs for a technology and knowledge $\operatorname{transfer}^{38}$.

\section{Conclusion}

Some of the biggest OEMs promote HEV technology as the best alternative to increase vehicle efficiency. Most press articles and corporate literature published by HEV manufacturers and suppliers look at HEV with optimism. Opponents to HEV obviously attack the technology with strong arguments against its technical complexity and challengeable overall efficiency.

Indeed political pressures are also involved in the game. The three American OEMs, namely GM, Ford and Chrysler, recently urged President Bush to financially and politically support a national technological solution for hybrids, independent from the currently dominant solutions initiated by Toyota.

However, HEV technology is only one subset in the wide range of measures to lower fuel consumption. The main aims of current vehicle development, to increase fuel efficiency while lowering weight and costs can be solved alternatively as shown with current diesel models or intelligent cost-efficient solutions as the BMW example shows.

Consumers' buying decisions are driven by factors different than financial ones only. These are dynamic in nature due to an ongoing public discussion on climate change and related changes within macro-economic factors such as taxes. Anticipating these changes will be central to successfully marketing cars in the future.

This article comes to the conclusion that HEV will probably gain a significant market share in Japan and the United States due to market pressures, sustained by political lobbying, but will remain limited elsewhere in the mid-term. One of the clearer uncertainties is the potential effect of a development of HEV market in China where environmental issues are of significant concern. Chinese OEMs could see the HEV as a solution for their growth in a very competitive globalized market. A positive driving force to $\mathrm{HEV}$ is certainly the difficulties identified by fundamental and applied research and development units with OEMs or component suppliers as well as public laboratories in developing more sophisticated technologies such as fuel cells or batteries for full electric drive trains. Such alternatives require breakthrough disruptive innovations and would probably emerge in the very long future, i.e. at least not before ten or even twenty years. In the meantime, HEV technology might have a real future.

But the complexity and high cost of the hybrid technology is also playing against itself. There is a huge strategic dilemma for the key players of the automotive industry where a mistake in technology decision making might turn even a big player into a take-over candidate. The next five years will provide industry observers with more accurate trends and success or failure factors.

\footnotetext{
${ }^{38}$ Frankfurter Allgemeine Zeitung, 20/03/2007.
} 


\section{References}

\section{Books and articles}

ASHLEY, S., (2002), Fuel cells start to look real, Automotive Engineering International Online, downloaded from http://southernnewengland.sae.org/automag/features/fuelcells/ on 27 August 2006.

de BANVILLE, E., CHANARON, J.J., (1991), Vers un système automobile européen, Paris, CPE-Economica.

BARDOU, J.P., CHANARON, J.J., LAUX, J., FRIDENSON, P., (1982), The Automobile Revolution, The Impact of an Industry, University of North Carolina Press, Chapell Hill.

BOHNER, M;, GSCHEIDLE, R;, KEIL, W. (1999), Fachkunde Kraftfahrzeugtechnik. Europa Lehrmittel, Haan-Gruiten.

CHANARON, J.J., A. NICOLON, (1976), Deux études de cas d'innovation I. Le véhicule électrique, II. Le TGV, ATP CNRS, IREP/IPEPS, Grenoble, janvier.

CHANARON, (1983), J.J., Progrès technique et industrie automobile, L'Etat des Sciences et des Techniques 1983, Paris, La Découverte Maspero, pp.492-493.

CHANARON, J.J., (1994), Perspectives de la voiture électrique : les leçons de l'histoire, Revue de l'Energie, numéro spécial Energie, Transports, Environnement, 463, novembre, pp. 627-635.

CHANARON, J.J., (1998), Automobiles: a static technology, a "wait-and-see » industry?, in CHANARON, J.J., BYE, P., Guest Editors, Technological Change and Inertia: Case Studies, A special Issue of The International Journal of Technology Management, 16, $\mathrm{n}^{\circ}$, pp.595630 .

CHANARON, J.J., (2003), Le temps de l'innovation, R\&D La Route de l'Innovation, Octobre, pp. 41-44.

CHANARON, J.J., FAUDRY, D., (2005), L'innovation dans les transports terrestres : Un Etat des lieux des recherches en socio-économie, 2001 Plus..., n 65, Novembre, pp. 3-70.

CHANARON, J.J., ORSELli, J., (2002), A qui profite le spectacle ?, La Recherche, 357, Octobre, pp. 70-73.

CONNORS, S.R., (2005), Technological Opportunities and Challenges to Achieving Sustainable Mobility, MIT, Analysis Group for regional Energy Alternatives, 7 November, Downloaded from http://web.mit.edu/connorsr/www/docs/Connors_AGSMobility_Nov05.pdf on 30th August 2006.

DEMIRDOVEN, N. DEUTCH, J., (2004), Hybrid Cars Now, Fuel Cell Cars Later, Science, 305, pp. 975-976. 
GREENE, D.L., DULEEP, K.G., MCMANUS. W., (2004). Future Potential of Hybrid and Diesel Powertrains in the U.S. Light-Duty Vehicle Market, ORNL/TM-2004/181, Oak Ridge National Laboratory, Oak Ridge, Tennessee, August 2004.

HEKKERT, M., VAN DEN HOED, R., (2004), Competing Technologies and the Struggle towards a New Dominant Design, The Emergence of the Hybrid Vehicle at the Expense of the Fuel Cell Vehicle?, Greener Management International, Autumn, 47, pp. 29-44.

JAMA, (2006), The Motor Industry in Japan 2006, Tokyo.

KISHI, K., SATOH, K., (2005), Evaluation of Willingness to Buy a Low-pollution Car in Japan, Journal of the Eastern Asia Society for Transportation Studies, 6, pp. 3121-3134.

Klein, J. (2007), Why People really buy Hybrids, Topline Strategy Group. [online] Available at http://www.toplinestrategy.com/Topline_Strategy_Report_Why_People_Really_Buy_ Hybrids.pdf [15.05.2007].

NICOLON, A., (1977), Le Véhicule Electrique, Paris Editions du CNRS, Coll. Energie et Société.

SANCHEZ-REPILA, D., POXON, J.E.W., (2006), Hybrid Electric Vehicles: Current Concepts and Future Market Trends, Rama de Estudiantes del IEEE de Barcelana, Buran, 23, March.

STRUBEN, J., STERMAN, J.D., (2006), Transition Challenges for Alternative Fuel Vehicle and Transportation Systems, MIT Sloan School of Management, Engineering System Division, ESD-WP-2006-06, Downloaded from http://esd.mit.edu/staging///wps/esdwp-2006-06.pdf on 30th August 2006.

TESKE, J., (2006), The Hybrid Car Market in the US, Scenarios for 2015, MIB-GEM, Grenoble.

\section{Websites}

- Automotive Engineering International Online, SAE International: http://southernnewengland.sae.org/automag/.

- GreenHybrid: http://www.greenhybrid.com.

- US Department of Energy: http://www.fueleconomy.gov/feg/bestworst.shtml

- HybridCars: http://www.HybridCars.com 
Appendix. Back Statistics

Appendix A: Most Fuel Efficient Cars (by EPA Size Class)

\begin{tabular}{|c|c|c|}
\hline & City & Hwy \\
\hline \multicolumn{3}{|l|}{ Most Efficient Two Seaters } \\
\hline Honda Insight Hybrid- 3 cyl, 1 L, Manual(5) & 60 & 66 \\
\hline Honda Insight Hybrid - 3 cyl, 1 L, Automatic(variable) & 57 & 56 \\
\hline \multicolumn{3}{|l|}{ Most Efficient Minicompact Cars } \\
\hline MINI Cooper - 4 cyl, 1.6 L, Manual(5), Premium & 28 & 36 \\
\hline MINI Cooper - 4 cyl, 1.6 L, Automatic(variable), Premium & 26 & 34 \\
\hline \multicolumn{3}{|l|}{ Most Efficient Subcompact Cars } \\
\hline WW New Beetle (Diesel) - 4 cyl, 1.9 L, Manual(5) & 37 & 44 \\
\hline WW New Beetle (Diesel) - 4 cyl, 1.9 L, Automatic(6) & 35 & 42 \\
\hline \multicolumn{3}{|l|}{ Most Efficient Compact Cars } \\
\hline Honda Civic Hybrid - 4 cyl, 1.3 L, Automatic(variable) & 49 & 51 \\
\hline WW Golf (Diesel) - 4 cyl, 1.9 L, Manual(5) & 37 & 44 \\
\hline \multicolumn{3}{|l|}{ Most Efficient Midsize Cars } \\
\hline Toyota Prius (Hybrid) - 4 cyl, 1.5 L, Automatic(Variable), Regular & 60 & 51 \\
\hline Hyundai Elantra - 4 cyl, 2 L, Manual(5), Regular & 27 & 34 \\
\hline \multicolumn{3}{|l|}{ Most Efficient Large Cars } \\
\hline Hyundai Sonata - 4 cyl, 2.4 L, Manual(5), Regular & 24 & 34 \\
\hline Hyundai Sonata - 4 cyl, 2.4 L, Automatic(4), Regular & 24 & 33 \\
\hline \multicolumn{3}{|l|}{ Most Efficient Large Cars } \\
\hline Hyundai Sonata - 4 cyl, 2.4 L, Manual(5), Regular & 24 & 34 \\
\hline Hyundai Sonata - 4 cyl, 2.4 L, Automatic(4), Regular & 24 & 33 \\
\hline \multicolumn{3}{|l|}{ Most Efficient Small Station Wagons } \\
\hline Pontiac Vibe - 4 cyl, 1.8 L, Manual(5), Regular & 24 & 34 \\
\hline Toyota Matrix - 4 cyl, 1.8 L, Manual(5), Regular & 24 & 33 \\
\hline Scion xB - 4 cyl, 1.5 L, Automatic(4), Regular & 24 & 33 \\
\hline
\end{tabular}

Source: http://www.fueleconomy.gov/feg/bestworst.shtml.

Appendix B: Fuel Consumption of Three Competing Luxurious Station-Wagons

\begin{tabular}{|l|c|c|c|}
\hline Measures & BMW 535D & Mercedes-Benz E500 & Lexus GS450h \\
\hline Maximum speed & $250 \mathrm{~km} / \mathrm{h}$ & $250 \mathrm{~km} / \mathrm{h}$ & $250 \mathrm{~km} / \mathrm{h}$ \\
\hline Fuel consumption & & & \\
\hline Average & $8.6 \mathrm{~L} / 100 \mathrm{~km}$ & $10.3 \mathrm{~L} / 100 \mathrm{~km}$ & $8.8 \mathrm{~L} / 100 \mathrm{~km}$ \\
\hline Highway & $8.3 \mathrm{~L} / 100 \mathrm{~km}$ & $9.2 \mathrm{~L} / 100 \mathrm{~km}$ & $7.4 \mathrm{~L} / 100 \mathrm{~km}$ \\
\hline City & $10.3 \mathrm{~L} / 100 \mathrm{~km}$ & $12 \mathrm{~L} / 100 \mathrm{~km}$ & $11.1 \mathrm{~L} / 100 \mathrm{~km}$ \\
\hline Range & $810 \mathrm{~km}$ & $770 \mathrm{~km}$ & $730 \mathrm{~km}$ \\
\hline Weight & $1,820 \mathrm{~kg}$ & $1,920 \mathrm{~kg}$ & $1,890 \mathrm{~kg}$ \\
\hline
\end{tabular}

Source: Revue Automobile, 27/07/2006.

Appendix C: Consumption With and Without Air Conditioning and Heating

\begin{tabular}{|l|l|l|c|}
\hline & Without AC and Heating & With AC and Heating & $\Delta$ \\
\hline Honda Civic Gasoline & $6.8 \mathrm{~L} / 100 \mathrm{~km}$ & $7.1 \mathrm{~L} / 100 \mathrm{~km}$ & $+4 \%$ \\
\hline Honda Civic Hybrid & $4.9 \mathrm{~L} / 100 \mathrm{~km}$ & $6.5 \mathrm{~L} / 100 \mathrm{~km}$ & $+32 \%$ \\
\hline
\end{tabular}

Source: Le Figaro, 20/01/2006. 
Appendix D: $\mathrm{CO}_{2}$ Emissions in grams per kilometre

\begin{tabular}{|l|c|}
\hline Models & Emissions \\
\hline Smart For Two CDI (diesel) & 90 \\
\hline Toyota Prius II (hybrid) & 104 \\
\hline Citroën C2 1.4 HDI & 107 \\
\hline Renault Clio 1.5 DCI & 110 \\
\hline Toyota Land Cruiser SW TD (diesel) & 292 \\
\hline Volkswagen Touareg V10 (diesel) & 346 \\
\hline Ferrari Enzo (gasoline) & 545 \\
\hline
\end{tabular}

Source: Le Monde, 15/09/2005. 